\title{
The abundance and diversity of Mollusks in mangrove ecosystem at coastal area of North Sulawesi, Indonesia
}

\author{
DEWI WAHYUNI K. BADERAN ${ }^{1,2, v}$, MARINI SUSANTI HAMIDUN ${ }^{1,2, v \vee}$, RAMLI UTINA $^{1,2, v \vee v, ~ S U K I R M A N ~ R A H I M ~}{ }^{3}$, \\ RIFAL DALI ${ }^{3}$ \\ ${ }^{1}$ Department of Biology, Faculty of Mathematics and Natural Sciences, Universitas Negeri Gorontalo. J1. Jenderal Sudirman No. 6, Kota Gorontalo \\ 96128, Gorontalo Province, Indonesia. Tel.: +62-435-821125; Fax.: +62-435-821752. "email: dewi.baderan@ung.ac.id; " marinish70@ung.ac.id; \\ vrramli.utina@ung.ac.id \\ ${ }^{2}$ Coastal Ecology Based on Local Wisdom Research Center, Universitas Negeri Gorontalo. Jl. Jenderal Sudirman No. 6, Kota Gorontalo 96128, \\ Gorontalo Province, Indonesia \\ ${ }^{3}$ Demography and Environmental Studies, Postgraduate Program, Universitas Negeri Gorontalo. Jl. Jenderal Sudirman No. 6, Kota Gorontalo 96128, \\ Gorontalo Province, Indonesia
}

Manuscript received: 12 December 2018. Revision accepted: 13 March 2019.

\begin{abstract}
Baderan DWK, Hamidun MS, Utina R, Rahim S, Dali R. 2019. The abundance and diversity of Mollusks in mangrove ecosystem at coastal area of North Sulawesi, Indonesia. Biodiversitas 20: 987-993. The study reported in this paper sought to analyze the abundance and diversity of Mollusks species in the coastal mangrove areas of Panango in North Sulawesi, Indonesia. Data collected in the study lent support to policy making in reducing the loss of marine biotic species in the coastal mangrove areas. Data collection used stratified-random sampling method (plot size was $10 \mathrm{~m}$ x $10 \mathrm{~m}$ ) with three plots at each research station was used. Data analyzed by Odum formula for abundance, Shannon Wiener index for diversity and evenness index for evenness. The samples were collected from 2 research station covering 15 sampling sites. This research found 14 families of mollusks comprised of 11 gastropod families (21 species) and bivalve families ( 3 types). The highest of the relative density was found in Terebralia sp (24,24\%), and the lowest relative density was obtained (1,52\%) in the following species: Spondylus violaceus, Conus sp., Semiricinula turbinoides, and Faunus ater. The diversity index of mollusks species (Gastropoda and Bivalvia) at the observation station was classified as a high category, indicating by $H^{\prime}>3,32$ (Station I H'= 2,19 and Station II H'=2,12). The evenness value in range $0,4<\mathrm{e}<0,6$. This indicates that the Mollusks species found in the research site had a medium amount. This study suggests a need to regulate mangrove areas of Panango for sustainable mangrove ecosystems management.
\end{abstract}

Keywords: Abundance, bivalvia, diversity, gastropods, Panango

\section{INTRODUCTION}

The coastal ecosystem is essential in maintaining environmental and climate balance. Mangrove ecosystem is among the examples of such an ecosystem that plays a significant ecological role. Mangrove ecosystem is located between the mainland and the sea, where changes continually occur, allow varied species of biota possess the ability to continuously adapt with such a unique environment (Kordi 2012). Lisna et al. (2017) further argue that the mangrove ecosystem significantly contributes to the life of the organisms in the coastal and marine areas.

The function of mangrove as the habitat for the aquatic animal is due to the fact that the area provides weathered materials or weathering litter that further turn into nutrients. Furthermore, the mangrove and other organisms, e.g., Mollusks (gastropods and bivalves) family benefit from the nutrients within the area. Dewiyanti and Sofyatuddin (2011) further emphasize the notion of the contribution of mangrove areas to providing food for diverse macrofauna unique to this area, such as crabs.

Macintosh et al. (2002) point out that Mollusks is among the organisms that significantly contribute to the ecological function of mangrove. These organisms serve as a bioindicator or aquatic ecosystem; some examples of the Mollusks are from macrozoobenthos phylum, i.e., Gastropods and Bivalvia. Yap and Noorhaidah (2011) add that gastropods can function as biomonitor. Some kinds of Mollusks such as Potamididae family, Neritidae, and Cerithidea are the species of the habitat of mangrove. (Arbi 2008; Cappenberg 2006). However, the gastropods should possess some characteristics, such as non-migratory, excessive in its number, having a high lifespan tend to have a large size, and coming into contact with basic sediments. The group of Mollusks of mangrove as the part of the mangrove ecosystem has an important role either direct or indirect role to support the function of mangrove.

Panango is among the coastal areas in the South Bolaang Mongondow District, North Sulawesi Province with an abundance of mangrove tree species spreading in the Tomini Bay. The areas are maintained with a variety of mangrove trees, such as Rhizophora spp, Bruguiera gymnorrhiza, Sonneratia alba, Nypa fruticans, Xylocarpus granatum, Avicennia spp, Derris trifoliata, and Ipomea pes-caprae. Panango also functions as a conservation area for fish and clam population. The coastal community utilizes the coastal area for fisheries, some of the wellknown fish species are Carangoides sp. and Siganus sp. 
However, the details on the species of Mollusks in the area are left unexplored. This suggests an immediate action to discover the abundance and diversity of Mollusks as the element of the mangrove ecosystem.

This study is aimed at analyzing the abundance and variety of Mollusks in the coastal area of Panango. It is expected that this study provides a grounding for the decision-making process in designing policy to prevent the decline in the number of aquatic species in such area.

\section{MATERIALS AND METHODS}

\section{Study area}

This research was conducted at the coastal area of Panango, South Bolaang Mongondow District, North Sulawesi Province, Indonesia (Figure 1) for three months starting from December 2017 to March 2018. The research site was 2 station and 15 sample point. The methods used explorative survey method. The primary data were generated by identifying all Mollusks species, i.e. gastropods and bivalves, the abundance and diversity of Mollusks in the research site. The level of diversity of the organism was analyzed using stratified random sampling (Figure 2).
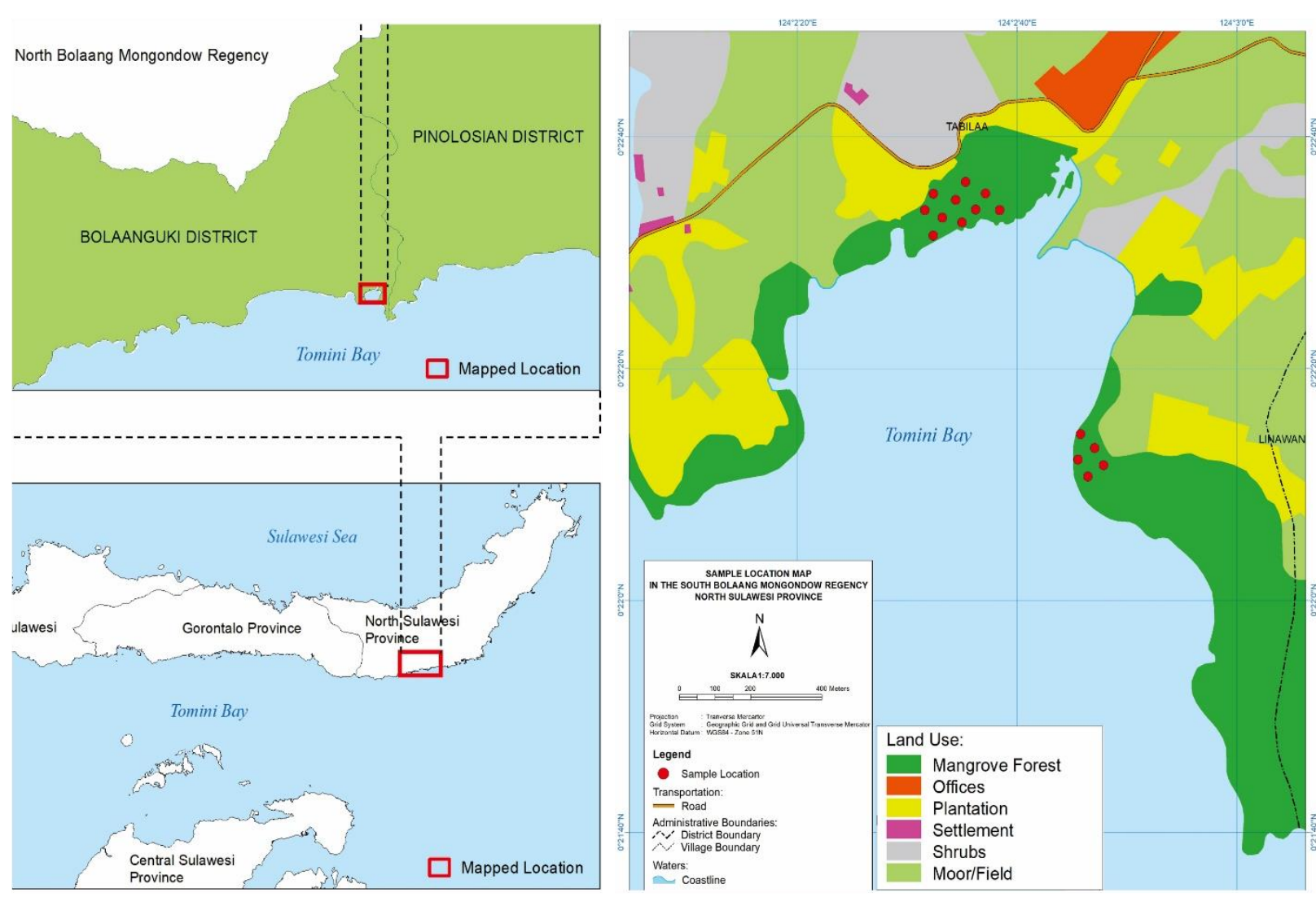

Figure 1. Research site, mangrove ecosystem at Panango Coastal Area, North Sulawesi Province, Indonesia

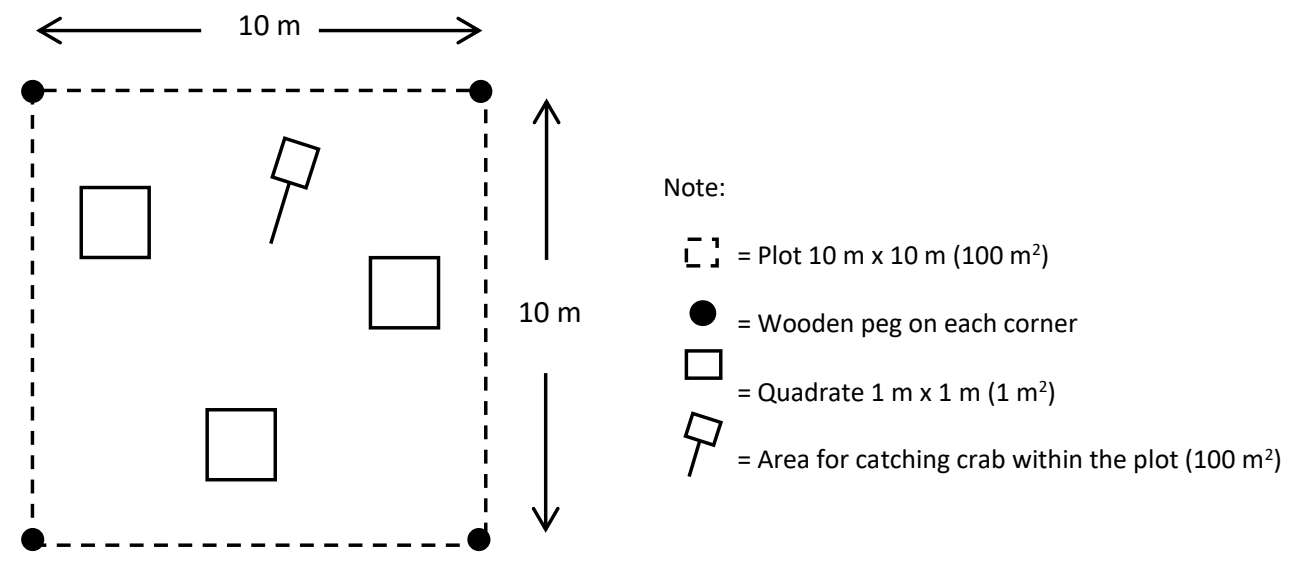

Figure 2. Determining the location of transect and plot in a site area (Chapman 1998) 


\section{Generating the data on the abundance and diversity of mollusks}

The sampling of Mollusks (Gastropods and Bivalvia) was conducted using stratified random sampling. There were three plots of the samples consisted of three with the dimension $10 \mathrm{~m} \times 10 \mathrm{~m}\left(100 \mathrm{~m}^{2}\right)$ on each site area. The sample was taken from each plot by using a quadrate measuring at $1 \mathrm{~m} \mathrm{x} 1 \mathrm{~m}\left(1 \mathrm{~m}^{2}\right)$; there are nine quadrates in total in each site. Every $100 \mathrm{~m}^{2}$ in each plot was scrutinized to collect the Mollusks sample that was yet to be found in the quadrate $1 \mathrm{~m}^{2}$.

The Mollusks samples were collected from the $1 \mathrm{~m}^{2}$ quadrate that was positioned randomly under the peg in the mangrove area, this quadrate must be positioned in an area where Mollusks are easily spotted. All the Mollusks were collected from the surface of the substrate and were excavated from the sediment to a depth of $20 \mathrm{~cm}$ for 15 minutes. The parts of the tree, i.e., stem and branch, were observed to a height of 1.5-2.0 $\mathrm{m}$ from the mud surface to collect the sample of species. Rotten wood was also examined to collect other species of Mollusks. The gathered samples were released to its habitat immediately once the data, such as the number and the information regarding the species, were recorded. Only the samples where the data are not that detailed were identified in a laboratory, with use literature by result of Dharma et al. (2005) study, recent and fossil Indonesian shells, and Marwoto et al. (2011) study, freshwater conch of Java Island (Molluscs; Gastropoda).

The following is used to calculate the abundance of each species using Odum and Barrett formula (2004).

$$
K=\frac{\text { the amount of the species i }}{\text { the number of individuals of all species }} \times 100 \%
$$

The abundance criteria: Michael (1995)

$$
\begin{array}{ll}
0 & \text { : nothing } \\
1-10 & : \text { less } \\
11-20 & : \text { enough } \\
>20 & : \text { many }
\end{array}
$$

Besides, it also calculates the index of the diversity and the evenness (Krebs 1972), the following is:

$$
\mathbf{H}^{\prime}=-\Sigma \mathrm{Pi} \ln \mathrm{Pi}
$$

Where:

$H^{\prime} \quad$ : diversity index Shannon-Wiener

$\mathrm{Pi}:$ ni/ $\mathrm{N}$ is the comparison of the number of species (ni) to the total of individuals $(\mathrm{N})$.

$$
\mathbf{E}=\frac{\mathrm{H}^{J}}{\mathrm{H}^{J} \text { maks }}=\frac{\mathrm{H}^{J}}{\operatorname{In} \mathrm{S}}
$$

Where:

$\mathrm{E} \quad$ : evenness index

$\mathrm{H}^{\prime} \quad$ : diversity index

$\mathrm{H}^{\prime} \max :$ maximum diversity

$\mathrm{S} \quad$ : the number of species

The evenness criteria:

\begin{tabular}{lll}
\hline \multicolumn{1}{c}{ E value } & $\begin{array}{c}\text { Condition of community } \\
\text { structures }\end{array}$ & \multicolumn{1}{c}{ Category } \\
\hline$>0.81$ & Very equally & Very good \\
$0.61-0.80$ & More equally & Good \\
$0.41-0.60$ & Equally & Medium \\
$0.21-0.40$ & Fairly equally & Poor \\
$<0.20$ & Not equally & Very poor \\
\hline
\end{tabular}

\section{RESULTS AND DISCUSSION}

\section{Mollusks classification}

Based on the result in Table 1 shows that 14 families of Mollusks comprising 11 gastropods family (21 species) and three Bivalvia families (three species) has discovered. The gastropod families consist of Potamididae, Muricidae, Conidae, Ellobiidae, Pachychilidae, Littoriniae, Assiminidae, Tochidae, Phytiidae, Turrilellidae, and Neritidae. The Bivalvia families are Arcidae, Cyrenidae, and Spondylidae.

Table 1. Mollusks classification discovered in two research sites, Panango Coastal Area, North Sulawesi, Indonesia

\begin{tabular}{llcrl}
\hline Class, Family & Species & $\begin{array}{c}\text { Station } \\
\text { No. }\end{array}$ & $\begin{array}{l}\text { No. } \\
\text { ind. } \\
\text { ind }\end{array}$ \\
\hline
\end{tabular}

\section{Gastropod}

Potamididae

Cerithidea quadrata

Cerithideopsis largillierti

Telescopium telescopium

Terebralia sp.

Terebralia sulcata

Littorinidae

Littoraria pallescens

Littoraria lutea

Neritidae

Nerita planospira

Vittina coromandeliana

Vittina turrita

Muricidae

Ellobiidae

Ellobiidae

Turritellidae

Assimineidae

Tochidae

Conidae

Pachychilidae

Bivalvia

Arcidae

Cyrenidae

Spondylidae

Total

Anadara cf. antiquata

Geloina expansa

Spondylus violaceus
Littoraria scabra

$$
\begin{array}{lll}
- & \checkmark & 32 \\
- & \checkmark & \\
- & \checkmark & \\
\checkmark & \checkmark & \\
\checkmark & \checkmark & \\
\checkmark & \checkmark & 24 \\
- & \checkmark & \\
- & \checkmark & \\
- & \checkmark & 31 \\
- & \checkmark & \\
- & \checkmark & \\
\checkmark & \checkmark & 11 \\
\checkmark & \checkmark & \\
\checkmark & - & \\
- & \checkmark & 8 \\
- & \checkmark & 1 \\
\checkmark & - & 7 \\
\checkmark & - & 6 \\
\checkmark & - & 5 \\
\checkmark & - & 1 \\
\checkmark & - & 1
\end{array}
$$

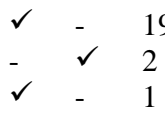

149

Notes : $\checkmark$ : found-: not found 

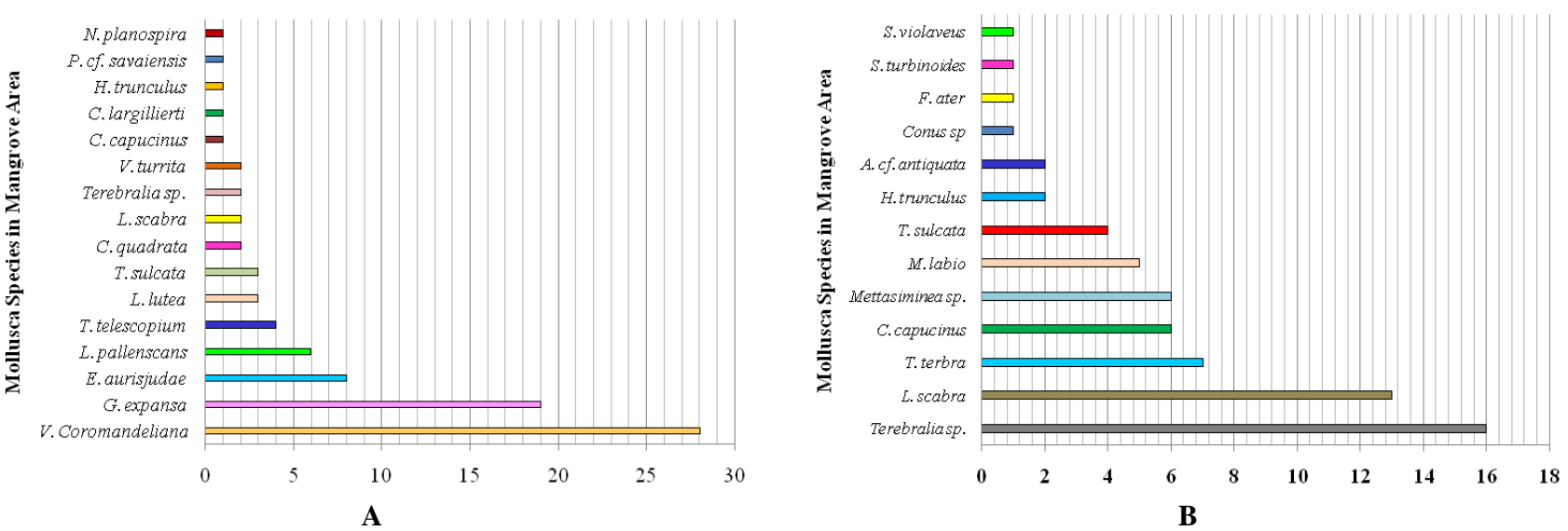

Figure 3. Number of individual and abundance of mollusks in the research sites, Panango Coastal Area, North Sulawesi, Indonesia. A. Station 1, B. Station 2

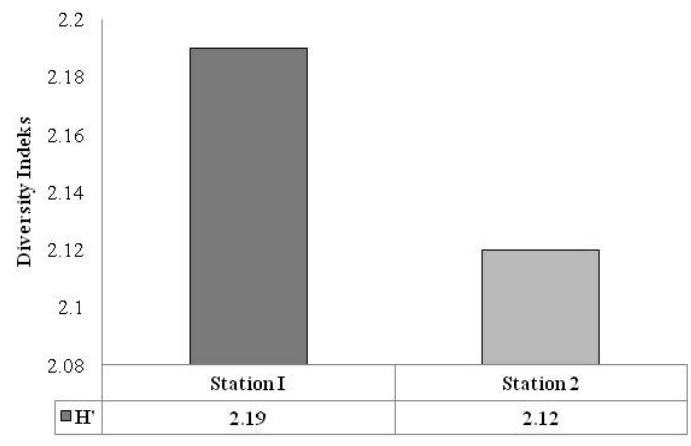

Figure 4. Mollusks diversity index in the research site, Panango Coastal Area, North Sulawesi, Indonesia

\section{Number of individuals and the abundance of mollusks in the research site}

It is revealed that the species Terebralia sp. has the highest value of relative abundance in station I. In addition, the relative abundance of Potamididae family is valued at $24.24 \%$ with a total of 16 samples (individuals) collected. Species with the lowest value of relative abundance are $S$. violaceus, Conus sp., S. turbinoides, and Faunus ater; each of these species is valued at $1.52 \%$. In station II, the species Vittina coromandeliana family Neritidae, with the value of relative abundance $33.33 \%$ (28 individuals), outnumber other species with the lowest value, such as Chicoreus capucinus, Cerithideopsis largillierti, Hexaplex trunculus, Phytia cf. savaiensis, and Nerita planospira with the percentage at $1.19 \%$ each. Figure 3 provides detailed information regarding this.

Mollusks diversity in the research site

The index of the diversity of Mollusks in the site area is considered high with $\mathrm{H}^{\prime}>3.32$; it ranges from 2.19-2.12; this is depicted in the following Figure 4.

\section{Mollusks evenness in the research site}

The evenness index can be described as a community condition in a particular ecosystem. The evenness index (E) reflects the wealth of each species. The index value of the evenness which is close to 1 is representing the amount of the individual that is relatively similar, moreover, if it is

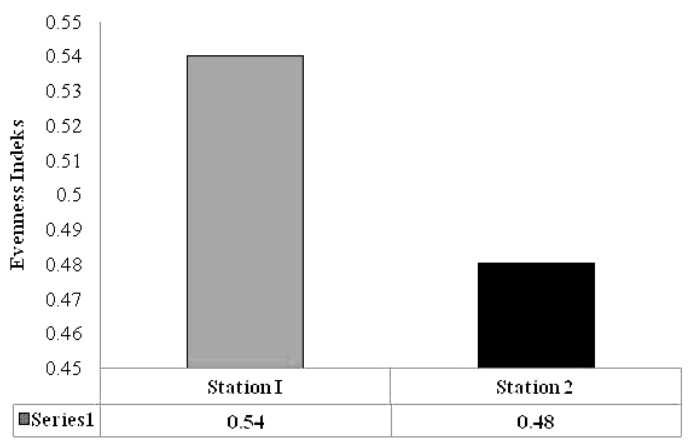

Figure 5. The evenness index of mollusks in research site, Panango Coastal Area, North Sulawesi, Indonesia

close to 0 , it means that the amount of the individuals of the species are different. The result of the calculation of the evenness index in the mangrove of Panango has the value 0,54 which means that each species living in this area has the evenness of mollusks are medium. This is based on the evenness index criteria that is $0,4<\mathrm{e}<0,6$. This showed that the condition of the community structures is in the equally level or in a "medium" category. The evenness index of Mollusks presented in Figure 5.

\section{Environmental factor in the research site}

The environment factor has an important role to support the growth of all living things including Mollusks, making the environment an important part of this research. The parameter measured during the sample collections is $\mathrm{pH}$ and temperature. The measurement results showed a varied $\mathrm{pH}$, ranging from 6-7.4 with the lowest values in the station I transect 3. The salinity in the station I transect 1 and station II transect 3 outweighs those in other stations with the value of $30 \mathrm{ppt}$. The temperature of the aquatic environment in the observation station ranging from 28.5$30^{\circ} \mathrm{C}$. This is caused by the rain occurred during the observation which increases the volume of the water in the areas. These stations are also located next to the sea whereas the salinity of the water almost reaches the value of those of saltwater. The $\mathrm{pH}$ of the aquatic environment is neutral and even close to the alkaline. 
Table 2. The result of measurement on environmental factor in the research site, Panango Coastal Area, North Sulawesi, Indonesia

\begin{tabular}{|c|c|c|c|c|c|}
\hline \multirow{2}{*}{ Station } & \multirow{2}{*}{$\begin{array}{c}\text { Coordinate } \\
\text { point }\end{array}$} & \multirow{2}{*}{ Transect } & \multicolumn{3}{|c|}{ Environ parameter } \\
\hline & & & pH & Sal. (ppt) & Temp. $\left({ }^{\circ} \mathrm{C}\right)$ \\
\hline \multirow[t]{6}{*}{$\bar{I}$} & $\mathrm{~N} \mathrm{0} 22^{\prime} 14.430^{\prime \prime}$ & 1 & 7.4 & 30 & 30 \\
\hline & E $124^{\circ} 2^{\prime} 45.802^{\prime \prime}$ & & & & \\
\hline & $\mathrm{N} 0^{\circ} 22^{\prime} 13.562^{\prime \prime}$ & 2 & 7.2 & 29 & 28.8 \\
\hline & E $124^{\circ} 2^{\prime} 46.770^{\prime \prime}$ & & & & \\
\hline & $\mathrm{N} 0^{\circ} 22^{\prime} 11.820^{\prime \prime}$ & 3 & 6.0 & 28 & 28.5 \\
\hline & E $124^{\circ} 2^{\prime} 47.638^{\prime \prime}$ & & & & \\
\hline \multirow[t]{6}{*}{ II } & N 022' 34.262" & 1 & 7.0 & 27.8 & 28.5 \\
\hline & E $124^{\circ} 2^{\prime} 36.067^{\prime \prime}$ & & & & \\
\hline & N $0^{\circ} 22^{\prime} 34.352^{\prime \prime}$ & 2 & 7.3 & 29.4 & 28.6 \\
\hline & E $124^{\circ} 2^{\prime} 34.116^{\prime \prime}$ & & & & \\
\hline & N $0^{\circ} 22^{\prime} 33.766^{\prime \prime}$ & 3 & 7.4 & 30 & 29.7 \\
\hline & E $124^{\circ} 2^{\prime} 32.939^{\prime \prime}$ & & & & \\
\hline
\end{tabular}

\section{Discussion}

Macrozoobenthos is a decomposer that breaks down weathered leaves where bacteria and fungi further turn the organic material into protein and carbohydrate (Fitriyani et al. 2016). Such organic materials, spread by organic litter that fell onto the soil, significantly contribute to the mangrove forest. The litter that will be decomposed into nutrients serves as the energy resources of macrozoobenthos. This nutrients also help the growth of mangrove trees.

This research reveals that the Mollusks families in the site area are Potamididae, Littorinidae, Neritidae, dan Cyrenidae; these families are common to the mangrove ecosystem. These families are categorized as Gastropoda. In the station II, there are many Gastropoda found during the research. They can adapt well to the mangrove environment. Therefore, they can live longer than other classes. Maturbongs et al. (2017) stated that one of Gastropoda dominating in the mangrove site is Potaminidae family.

Some Mollusks living in the center of the forest is $C$. quadrata, T. telescopium, N. planospira, E. aurisjudae, L. scabra, and $C$. capunicus. The number of $L$. scabra species dominates other species discovered in the area, such as in station I and II. In these stations, the fishing net whose function is to catch the organic litter is put between mangrove trees. Its location is distant from the tide and is a shady area. Budiman (1991) suggests that the L. scabra species lives on the stem, branch, root, and leaf of a mangrove tree. It can survive by only consuming water splash from the tide. The distribution of this species is determined by factors, such as the function of an area as the shelter for the Mollusks and the type of vegetation. This Mollusks can crawl to a higher place by its slime in most of the vegetation.

A condition of the environment of the research site is considered optimum for Mollusks to survive and reproduce thanks to the temperature ranging from $28.5-30^{\circ} \mathrm{C}$. These findings are in line with Hicks and McMohan (2002) explaining that the optimum temperature for Mollusks ranges from $15-28^{\circ} \mathrm{C}$ while the best temperature range for Bivalvia is $20-30^{\circ} \mathrm{C}$.
The level of acidity in the research site is between 6.07.4 by which suitable for Mollusks. If the $\mathrm{pH}$ is higher than 9 and lower than 5, Mollusks will be unlikely to survive in this area. This finding resonates with the results seen in Russel-Hunter (1968); Alfitriatissulus (2003) that the best $\mathrm{pH}$ to support the life of Mollusks ranges from 6.5-7.5. Salinity in the site of research ranges from 27.8-30 ppt where it is considered by Nybakken (2004) as a suitable salinity level for Bivalvia to survive.

Based on the measurement results, it is obtained that the water temperature in the research site is $28.5-30^{\circ} \mathrm{C}$ which also suitable for Mollusks. This is emphasized by Hicks and McMohan (2002) that generally the optimum temperature for Mollusks is $15-28^{\circ} \mathrm{C}$. Furthermore, the optimum temperature for Bivalvia is $20-30^{\circ} \mathrm{C}$. Masrur (2015) stated that the optimum temperature for Gastropoda is $25-32^{\circ} \mathrm{C}$. If the temperature is above $32^{\circ} \mathrm{C}$, the metabolic process will be interrupted. Moreover, the optimal temperature for Bivalvia is $25-28^{\circ} \mathrm{C}$. If the temperature is higher than the optimum one, it is not suitable for its growth. The change of the temperature beyond the limit of the optimum one will affect the decrease of the growth and organism reproduction.

It can be concluded that the biotic mostly found in Panango is Mollusks (Gastropoda and Bivalvia). There are 11 Gastropoda families covering 22 species, and 3 families of Bivalvia covering 3 species. The Gastropoda families are Potamididae, Muricidae, Coccidae, Ellobidae, Pachychilidae, Littorinidae, Assimineidae, Tochidae, Phytiidae, Turritellidae, and Neritidae families. Moreover, the Bivalvia families are Arcidae, Cyrenidae, dan Spondylidae families. Purnama et al. (2011) stated that a community could be considered to have a high species diversity if that community is arranged by many species with similar types. On the contrary, if the community is arranged by little types of living things and these little types are dominant so that the diversity of the species is low. The high diversity showed that a community has a high complexity because there is also a high interaction among the species. Therefore, in community with high diversity, there will be energy transfer, predation, competition, and division of the niche, then theoretically it would be more complicated. The index of the abundance is seen by the criteria so that the community in the research site is categorized in a "very equally or even" with a very good category.

The value of evenness in the research site $0.4<\mathrm{e}<0.6$. This indicates that the Mollusks species found in the research site had a medium amount. This condition also describes that there is no competition among the Mollusks species in acquiring food source and place or space (Capanberg 2016). Odum and Barrett (2004) argued that the evenness of the species would be high if there will be a dominated individual by a particular species, besides, the more value of the evenness, the more diversity of the community. Therefore, the index value of the evenness of the species can be used in order to describe the stability of the community. 


\section{ACKNOWLEDGMENTS}

The authors thank those people and institutions in contributing as well as supporting this research. The authors also would like to thank the postgraduate program of population and living environment, Universitas Negeri Gorontalo, Indonesia for its administrative support in conducting this research and all the government in South Bolaang Mongondow District of North Sulawesi Province, Indonesia as well as BKSDA who have provided the supporting data and references while conducting this research. Moreover, the authors also express their gratitude for all the teams who have helped the author in collecting the data.

\section{REFERENCES}

Arbi UY. 2008. Molluscs community in the tambak wedi mangrove ecosystem, Madura Strait, Surabaya, Jawa Timur. Oceanologi dan Limnologi Indonesia 34 (3): 411-425. [Indonesian]

Barus TA. 2004. Introduction to limnology: A study of river and lake ecosystems. Department of Biology, Faculty of Mathematics and Science, USU, USU Press Medan. [Indonesian]

Budiman A. 1991. An Analysis of Several Gatra Ecology of Indonesian Mangrove Molluscs. [Dissertation]. Universitas Indonesia, Jakarta [Indonesian]

Cappenberg HAW, Azis A, Aswandy I. 2006. Molluscs community in the waters of Gilimanuk Bay, Bali Barat. Oseanologi dan Limnologi di Indonesia 40: 53-64. [Indonesian]

Cappenberg HAW. 2016. Molluscs in Kabaena, Muna, and Buton island southeast Sulawesi. Oseanologi dan Limnologi di Indonesia 1 (2): 61 72. [Indonesian]
Chapman MG. 1998. Relationships between spatial patterns of benthic Assemblages in mangrove forests using different levels of taxonomic resolution. Mar Ecol Prog Ser 162: 71-78.

Dewiyanti I, Sofyatuddin K. 2011. Diversity of gastropods and bivalves in mangrove ecosystem rehabilitation areas in Aceh Besar and Banda Aceh Districts, Indonesia. AACL Bioflux 5 (2): 55-59.

Dharma B, Schwabe E, Schrodl M. 2005. Recent and Fossil Indonesian Shells. University of California, USA.

Hicks DW, McMohan RF. 2002. Temperature Acclimation of upper and lower thermal limits and freeze resistance in the nonindigenous brown mussel, Perna perna (L) from Gulf of Mexico. Mar Biol 140: 11671179

Kordi M. 2012, Mangrove ecosystem, potential, function and management. Rineka Cipta, Jakarta. [Indonesian]

Krebs CJ. 1972. Ecological Methodology. Harper Collins Publisher, New York.

Macintosh DJ, Ashton EC, Havanon S. 2002. Mangrove rehabilitation and intertidal biodiversity: A study in the Ranong Mangrove Ecosystem, Thailand. Estuar Coast Shelf Sci 55: 331-345.

Marwoto RM, Isnaningsih NR, Mujiono N, Heryanto, Alfiah, Riena. 2011. Freshwater Conch of Java Island (Molluscs; Gastropoda). Pusat Penelitian Biologi, LIPI, Bogor. [Indonesian]

Masrur MI. 2015. The spatial distribution of gastropods and their relation to environmental characteristics in the coastal of Nusalaut, Maluku Tengah. Jurnal Ilmu dan Teknologi Kelautan Tropis 7 (1): 365-378. [Indonesian]

Maturbongs MR, Novel NR, Sisca E. 2017. The density and species diversity of gastropods during east season in the mangrove ecosystem of Kembi Beach in Merauke. Jurnal Agricola 7 (2): 149-156. [Indonesian]

Nybakken JW. 2004. Marine Biology: An Ecological Approach. 6 ed. Benjamin Cummings, New York.

Odum E, Barrett GW. 2004. Fundamentals of Ecology, 5th ed. Cengage Learning, New York.

Purnama PR, Nastiti NW, Agustin ME, Affandi M. 2011. Gastropod Diversity on the Sukamade River, Meru Betiri National Park, East Java. Berkala Penelilitian Hayati 16: 143-147. [Indonesian] 